\title{
Using Tithonia diversifolia (Hemsl.) Gray in a Short Fallow System to Increase Soil Phosphorus Availability on a Costa Rican Andosol
}

\author{
Pedro S. Jorge Mustonen \\ Department of Agronomy, Jorge \& Mustonen C.x A., Santo Domingo, Dominican Republic \\ Tel: 809-563-4206 E-mail: compay1_rd@hotmail.com \\ Maren Oelberman (Corresponding Author) \\ Department of Environment and Resource Studies, University of Waterloo, Canada \\ Tel: 1-519-888-4567 E-mail: moelbermann@uwaterloo.ca
}

Donald C.L. Kass

Northeast Regional Laboratory, Food and Drug Administration, 158-15 Liberty Avenue, Jamaica, USA

Tel: 1-718-340-5434_E-mail: dclk9@hotmail.com

$\begin{array}{lc}\text { Received: May 27, } 2011 & \text { Accepted: June 15, } 2011 \quad \text { Online Published: December 21, } 2011 \\ \text { doi:10.5539/jas.v4n2p91 } & \text { URL: http://dx.doi.org/10.5539/jas.v4n2p91 }\end{array}$

The research is financed by the University of Wales and the Danish Institute of Agricultural Sciences

\begin{abstract}
The present study evaluated aboveground pruning biomass production in a naturally regenerated fallow (NF), and in monoculture with a leguminous species (CF), and a non-leguminous species (TF) on an Andosol in Costa Rica. The effect of pruning biomass removal or addition on bean grain yield and soil $\mathrm{P}$ fractions was also evaluated. Biomass production and nutrient input was significantly greater $(p>0.05)$ in the TF treatment. Macronutrient content of the pruned biomass was not significantly different $(p>0.05)$ between treatments, but $\mathrm{C} / \mathrm{N}$ and $\mathrm{C} / \mathrm{P}$ ratios were significantly lower $(\mathrm{p}>0.05)$ in the $\mathrm{CF}$ treatment. Bean grain yields were significantly greater $(p>0.05)$ only when TF biomass was added to the soil as mulch. There was no significant difference $(\mathrm{p}>0.05)$ in the amount of $\mathrm{P}$ in the labile and potentially labile fractions between treatments, and the inter-conversion mechanisms between non-labile soil $\mathrm{P}$ and labile fractions occurred in diverse directions, not necessarily following the inverse strength sequence of the Hedley $\mathrm{P}$ fractionation procedure.
\end{abstract}

Keywords: Bean cultivars, Cajanus cajan, Improved fallow, Labile P fractions, Legumes, Natural fallow, Pruning biomass, Soil phosphorus fractions, Tithonia diversifolia

\section{Introduction}

Soil phosphorus (P) deficiency is widespread in tropical agroecosystems, and is one of the largest constraints to food security. This is largely due to naturally low soil P stocks and the high fixation of this nutrient by iron and aluminium oxides (Zhongqi, Griffin, and Honeycutt, 2004). As a result, P is relatively immobile in the soil leading to a low availability for plant uptake (Oberson, Pypers, Bünemann, and Frossard, 2011). Tiessen, Stewart, and Cole (1984) suggested that in tropical agroecosystems, only $1 \%$ of the organic P pool is mineralized and available for plant uptake.

Current strategies to cope with low soil $\mathrm{P}$ availability include the use of biotechnology to help develop more efficient crop genotypes (Henry, Chaves, Kleinman, and Lynch, 2010), or through the addition of mineral fertilizer or animal manure (Opala, Okalebo, Othieno, and Kisinyo, 2010). However, modern crop genotypes and soil amendments such as manure or fertilizers are often not available, are difficult to access or are not economically feasible for the rural poor (Kwabia, Stoskopf, Palm, and Voroney, 2003; Opala et al., 2010). As such, agroecosystem management practices that help to maintain adequate levels of soil $\mathrm{P}$ for the continual and sustainable production of crops in tropical agroecosystems are needed (Zhongqi et al., 2004).

Management practices including improved fallow, where natural vegetation is intentionally replaced by planted leguminous or non-leguminous species high in nitrogen $(\mathrm{N})$ and $\mathrm{P}$, may help to replenish soil nutrients removed 
by growing crops and thereby help to maintain or increase crop yields (Kass and Somarriba, 1999; Partey, Quashie-Sam, Thevathasan, and Gordon, 2011), and may also be a more economical approach to increase soil fertility (Nziguheba, Palm, Buresch, and Smithson, 1998). As such, fallows may restore levels of soil organic matter and nutrients over the long-term and help improve crop grain yield over the short-term. This is because improved fallow systems have the ability to alleviate soil $\mathrm{N}$ deficiencies through biological $\mathrm{N}_{2}$-fixation and can also increase the availability of soil P (Muchane, Jama, Otheino, Okalebo, Odee, Machua, and Jansa, 2010). However, Palm, Myers, and Nandwa (1997) suggested that organic inputs typically provide an insufficient amount of $\mathrm{P}$ for crop growth because of relatively low concentrations of this nutrient in plant tissue, but can help to increase soil P availability. Cong and Merckx (2005) suggested that a higher soil P availability may due to an increase in soil $\mathrm{pH}$ leading to the solubility of phosphate sources. They also suggested that organic inputs may lead to a decrease in extractable aluminium resulting in a reduction in the fixation of added $\mathrm{P}$; an increase in macro-aggregation and reduced specific surface area and porosity leading to fewer P sorption sites; and an increase in negative charges at the soil surface leading to a net increase in the repulsive force for $\mathrm{P}$ (Cong and Merckx, 2005).

The Mexican sunflower [Tithonia diversifolia (Hemsl.) Gray] may be one plant species suitable for improved fallow systems and to help improve soil fertility and crop productivity due to its relatively high foliar nutrient content (Jama, Palm, Buresch, Niang, Gachengo, Nziguheba, and Amadalo, 2000; Muchane et al., 2010; Partey et al., 2011). For example, foliar analysis of $T$. diversifolia green biomass showed a greater concentration of all macronutrients compared to leguminous species commonly used as mulch or green manure in tropical Africa (Jama et al., 2000). Jama et al. (2000) also found that the application of T. diversifolia shoot biomass to a $\mathrm{P}$ deficient soil enhanced the soil microbial activity and microbial biomass, and increased soil $\mathrm{P}$ availability for plant uptake and crop grain yield. In Ghana, Partey et al. (2011) observed that T. diversifolia leaves had the greatest rate of decomposition and nutrient release rates when compared to four leguminous species (Senna spectabilis (DC.) H.Irwin \& Barneby, Gliricidia sepium (Jacq.)Walp., Laucaena leucacephala (Lam.)De Wit, and Acadia auriculiformis Benth.).

To date, the majority of studies on T. diversifolia and its potential to improve soil $\mathrm{P}$ availability for plant uptake have taken place in tropical Africa (Nziguheba et al., 1998; Gachengo, Palm, Jama and Othieno, 1999; Jama et al., 2000; Nziguheba, Merckx, Palm, and Mutuo, 2002; Opala et al., 2010; Partey et al., 2011), but less information is available from tropical Latin America (Phiri, Barrios, Rao, and Singh, 2001; Barrios, Cobo, Rao, Thomas, Amezquita, Jimenez, and Rondon, 2005; Basamba, Varrios, Singh, and Rao, 2008), where similar constraints of soil $\mathrm{P}$ availability exist. The objectives of this study were to evaluate aboveground biomass production in a naturally regenerated fallow, and in short fallows in monoculture with a leguminous species (Cajanus cajan (L.) Millsp.) and a non-leguminous species (T. diversifolia) on a Costa Rican Andosol. The effect of pruning biomass removal or addition from each of the fallow species on different soil $\mathrm{P}$ fractions and on the grain yield of two different Phaseolus vulgaris (L.) cultivars was also evaluated.

\section{Materials and Methods}

\subsection{Study Site}

The research site was located in San Juan Sur $\left(9^{\circ} 53^{\prime} \mathrm{N}, 83^{\circ} 38^{\prime} \mathrm{W}\right)$, Costa Rica. The average annual precipitation was $2,679 \mathrm{~mm}$ and the mean annual temperature was $21.8^{\circ} \mathrm{C}$. The site was located $950 \mathrm{~m}$ above sea level. The soil was classified as an Andosol (International Soil Reference and Information Centre, 1994), with a clay loam to clay texture, and a reddish-brown color. The soil structure and bulk density $\left(0.68 \mathrm{Mg} \mathrm{m}^{-3}\right)$ allowed for good internal drainage in the upper $20 \mathrm{~cm}$ of the soil profile. Prior to initiating our study, the soil was characterized $(0-20 \mathrm{~cm})$, with a $\mathrm{pH}$ (water) of 4.9 ; exchangeable acidity of $1.35 \mathrm{cmol}^{+} 1^{-1}$; and a low base status $\left(0.39 \mathrm{cmol}^{+}\right.$ $\left.\mathrm{kg}^{-1}\right)$. Values of exchangeable cations $\left(\mathrm{cmol}_{\mathrm{c}}^{+} 1^{-1}\right.$ ) ranged from 0.19 [calcium $(\mathrm{Ca})$ ], 0.13 [magnesium $(\mathrm{Mg})$ ] to $0.07(\mathrm{~K})$, with a $\mathrm{P}$ retention of $96.5 \%$ and availability of $3.5 \mathrm{mg} \mathrm{l}^{-1}$. The study site was surrounded by a very humid pre-montane (bvh-P) native tropical forest (Holdridge, 1987) and extensive agricultural production with beans (P. vulgaris), maize (Zea mays L.) and coffee (Coffea Arabica L).

Prior to initiating the field experiment, the site was ploughed three times in order to manage weeds and to accelerate the decomposition of naturally occurring vegetation. Preceding cultivation, the site was dominated by natural fallow vegetation and was not fertilized for two years. The experimental design was a randomized complete block design (RCBD) with three treatments: natural fallow (NF), an improved monoculture fallow with the leguminous species C. cajun (CF), and an improved monoculture fallow with the non-leguminous $T$. diversifolia (TF). Each treatment was replicated four times, and each treatment plot size was $5 \mathrm{~m} \times 6 \mathrm{~m}$. The NF was composed of existing pastures with a mixture of locally grown fallow species including leguminous and non-leguminous species and was the experimental control site (Mustonen, 2005). Improved monoculture fallow species were planted at a density of 60,000 plants ha ${ }^{-1}(0.30 \mathrm{~m}$ between plants and $0.4 \mathrm{~m}$ between rows $)$ to ensure the soil under the rows was permeated by roots. Cajanus cajan was sown directly into the soil using two seeds 
per planting hole, whereas $20 \mathrm{~cm}$ long $T$. diversifolia stakes were planted. The two improved fallow monoculture species were chosen because of their ability to increase levels of soil $\mathrm{P}$ and/or their ability to increase $\mathrm{P}$ availability for plant uptake (Adetunji and Okeleye, 2001; Aguiar, 2001).

\subsection{Fallow Species Biomass and Grain Yield}

Plant biomass from aboveground components of the fallow vegetation in each treatment was determined after 24 weeks of growth between July 2001 and August 2002. Within each treatment replication, the entire biomass was cut above the soil and its fresh weight was determined. For each treatment replication, a $500 \mathrm{~g}$ subsample representative of the different aboveground fresh biomass components (leaves, branches) was oven-dried at $60^{\circ} \mathrm{C}$ for $60 \mathrm{~h}$ to determine biomass dry weight. Dried biomass samples were ground to $1 \mathrm{~mm}$ using a Wiley ${ }^{\circledR}$ Mill (Thomas Model 4 Wiley ${ }^{\circledR}$ Mill, Thomas Scientific, Swedesboro, NJ), and analyzed for N (semi-micro Kjeldahl), $\mathrm{P}, \mathrm{K}, \mathrm{Ca}$ and $\mathrm{Mg}$ (wet digestion using 5:1 nitric-perchloric acid) (Sparks, 1996). Nutrient concentrations were expressed in $\mathrm{mg} \mathrm{g}^{-1}$ of dry weight. Biomass carbon (C) was estimated using a mean value of $44.78 \%$ (Cobo, Barrios, Kass, and Thomas, 2002).

Following biomass pruning in week 24, each treatment plot was split into four subplots ( $2.5 \mathrm{~m} \times 3 \mathrm{~m})$. Two of the four subplots were randomly selected for pruning biomass removal while the prunings remained on the soil surface as mulch in the other two randomly selected subplots. At this time two randomly selected subplots were seeded with two different $P$. vulgaris cultivars: Chirripo Rojo and Negro Huasteco. Each bean cultivar was seeded into a subplot with and without prunings. During the 90-day bean growing phase the plots were weeded manually and fallow species were pruned three times to minimize light competition with the growing crop. The pruned biomass was removed off-site. Bean grain yield was determined at crop maturity by harvesting only the pods and crop residues were left on site.

\subsection{Soil Sampling}

Soil was sampled in each treatment after 1, 18 and 23 weeks of fallow growth between July 2001 and August 2002. Four randomly selected locations, within each treatment replication and at each sampling week were used for sampling soil at 0-12 cm and 12-24 cm depths; using a soil corer with an inner diameter of $2.5 \mathrm{~cm}$. The extracted soil was air-dried and sieved $(2 \mathrm{~mm})$. Soil P concentrations were determined according to the Hedley fractionation procedure (Hedley, Stewart, and Chauhan, 1982) and subsequently analyzed using a UV-Vis spectrophotometer (Thermospectronic, Helios Alfha, Cambridge, UK). A total of seven P fractions were determined and grouped in four categories (Nwoke, Vanlauwe, Diels, Sanginga, Osombi, and Merckx, 2003): 1) $\mathrm{P}$ in the soil solution $(\mathrm{Pi}) ; 2)$ labile $\mathrm{P}\left(\mathrm{NaHCO}_{3}-\mathrm{Pi}\right.$ and $\left.\left.\mathrm{NaHCO}_{3}-\mathrm{Po}\right) ; 3\right)$ potentially labile $\mathrm{P}(\mathrm{NaOH}-\mathrm{Pi}$ and $\mathrm{NaOH}-\mathrm{Po}$ ); and 4) occluded P (HCl-Pi and Residual-P).

\subsection{Statistical Analysis}

All data were examined for homogeneity of variance and found to have normal distributions. Main effects were evaluated by analysis of variance (ANOVA) to quantify differences in aboveground biomass and nutrient content between NF, CF, and TF treatments using the general linear model procedure (GLMs) in SAS (SAS, 1999). To further compare differences between means, Duncan's multiple range test was used. Multivariate analysis (MANOVA) using Wilks' Lambda test was used to understand the differences and interactions between the soil P fractions because the data included simultaneous measurements on several soil $\mathrm{P}$ fractions at different sampling times (Steel, Torrie, and Dikey, 1997). For all statistical analyses the threshold of probability level for determining significant differences was $\mathrm{p}<0.05$.

\section{Results}

\subsection{Fallow Species Biomass and Grain Yield}

Aboveground biomass production, measured 24 weeks after planting, was significantly different between the fallow treatments (Fig. 1). The TF treatment had a significantly greater biomass production compared to the CF and NF treatments. Foliar nutrient concentrations (N, P, K, Mg, and $\mathrm{Ca}$ ) at week 24 were not significantly different between the fallow treatments (Table 1). However, nutrient input $\left(\mathrm{g} \mathrm{m}^{-2}\right)$ was significantly different between fallow treatments, where the TF treatment had the greatest input (Table 1). The $\mathrm{C} / \mathrm{N}$ and $\mathrm{C} / \mathrm{P}$ ratios also differed significantly between treatments with the greatest value occurring in the NF treatment followed by the TF and CF treatments (Table 1).

When comparing grain yield between fallow treatments for either bean cultivar and with pruned biomass removed, there were no significant differences (Table 2). However, the grain yield was significantly greater in the TF treatment without pruning biomass removal for the Chirripo Rojo cultivar. When comparing grain yield between bean cultivars within fallow and pruning treatments, there was no significant difference. When evaluating the mean difference for all three fallow treatments with respect to bean grain yield and pruning biomass removal or retention, there was an overall increase of $18.1 \%\left(0.15 \mathrm{Mg} \mathrm{ha}^{-1}\right)$ for Chirripo Rojo and 
$6.03 \%\left(0.05 \mathrm{Mg} \mathrm{ha}^{-1}\right)$ Negro Hueastco. Interaction effects of the bean cultivars with respect to pruning biomass removal or retention were not significant.

\subsection{Soil Phosphorus}

At each sampling time, all soil $\mathrm{P}$ fractions were significantly greater at a $0-12 \mathrm{~cm}$ depth compared to that at $12-24 \mathrm{~cm}$ (Table 3). After the 23 week experimental period $(0-12 \mathrm{~cm})$, approximately $6.3,6.2$ and $6.1 \%$ of the total soil $\mathrm{P}$ was held in the labile fraction in the NF, CF and TF treatments respectively. Comparatively, 53\% (CF and $\mathrm{TF}$ ) and $51 \%(\mathrm{NF})$ of the total soil $\mathrm{P}$ was held in the potentially labile fraction. At a sampling depth of 12-24 $\mathrm{cm}, 5.8,5.4$ and $5.3 \%$ of the total soil $\mathrm{P}$ was held in the labile fraction for the TF, NF and $\mathrm{CF}$ treatments respectively whereas $49 \%$ of the total soil $\mathrm{P}$ was held in the potentially labile fraction in all fallow treatments (Table 3).

The labile P fraction (0-12 cm) decreased with time (weeks 1, 18 and 23) in all three treatments, whereas the potentially labile P fraction showed no such trend (Fig. 2). Additionally, the labile P fraction was significantly greater in the NF treatment compared to the $\mathrm{CF}$ and $\mathrm{TF}$ treatments in week 1 and 23 , but was similar between the three treatments in week 18 . The potentially labile P fraction $(0-12 \mathrm{~cm})$ was not significantly different between treatments at any of the sampling times.

In each treatment, the residual-P and potentially labile $\mathrm{P}$ fractions were significantly greater compared to the labile, occluded, and soil solution fractions (Table 3). Over the 23 week experiment, the inorganic P (Pi) concentration in the soil solution at a $0-12 \mathrm{~cm}$ depth was $1 \mathrm{mg} \mathrm{P} \mathrm{kg}^{-1}$, whereas that at a $12-24 \mathrm{~cm}$ depth was 0.2 $\mathrm{mg} \mathrm{P} \mathrm{kg}{ }^{-1}$. When the amount of $\mathrm{P}$ in the soil solution (Pi) was expressed as a mean value over the 23 week experimental period comparing the different fallow treatments, results showed that the $T$. diversifolia fallow (TF) was significantly greater compared to the other treatments following a sequence of $\mathrm{TF} \approx \mathrm{CF}>\mathrm{NF}$. Differences between fallow treatments for the residual-P fraction followed a sequence of $\mathrm{NF}>\mathrm{TF} \approx \mathrm{CF}$, and that for $\mathrm{NaHCO}_{3}-\mathrm{Po}$ was $\mathrm{NF}>\mathrm{CF} \approx \mathrm{TF}$. No significant differences between treatments were observed for the $\mathrm{NaHCO}_{3}-\mathrm{Pi}$, $\mathrm{NaOH}-\mathrm{Pi}$ and $\mathrm{NaOH}-\mathrm{Po}$ fractions. All P-fractions increased significantly with length of the fallow period, showing the greatest accumulation of soil $\mathrm{P}$ at week 23 (Table 3).

When expressing the P-fractions as a mean value of the 23 week experimental period at a depth of $12-24 \mathrm{~cm}$, no significant differences were observed between the NF, CF and TF treatments for the different P-fractions. Only the Residual-P fraction was significantly greater in the NF and TF treatments at this soil depth. At this soil depth there was no clear trend with time and only the residual-P, labile, occluded and the potentially labile inorganic (NaOH-Pi) P fractions showed significant increases with the length of the fallow period (Table 3).

\section{Discussion}

\subsection{Fallow Species Biomass and Grain Yield}

Biomass production of the three different fallow treatments was similar compared to that of other studies (Rao and Gill, 1995; Jama et al., 2000; Oke, 2005; Rao and Northrup, 2009; Sao, Mui, and Binh, 2010). Despite the P limitation of the San Juan Sur soils, biomass production of the improved fallow treatments in monoculture with C. cajun (CF) or $T$. diversifolia (TF) were greater than that of the natural fallow (NF). The higher biomass production in the improved fallow with $C$. cajun compared to the NF was likely due the greater plant density of the $\mathrm{N}_{2}$-fixing C. cajun (Young, 2002). In Colombia, Barrios et al. (2005) found that all planted fallow systems in their study produced greater biomass than the natural fallow; and the fallow with $T$. diversifolia produced the greatest biomass $\left(1640 \mathrm{~g} \mathrm{~m}^{-2} \mathrm{y}^{-1}\right)$. The $51 \%$ greater aboveground biomass production in the TF treatment compared to that of the CF was likely due to a more efficient use of soil resources by the growing $T$. diversifolia plants and/or due to a different mechanism of soil nutrient acquisition. Mustonen (2005) found a greater root length and density in T. diversifolia compared to $C$. cajun when planted at 60,000 trees $^{-1}{ }^{-1}$; and suggested that this may result in an increased capacity of $T$. diversifolia to maximize nutrient acquisition. Garrity and Mercado (1994) suggested that $T$. diversifolia may have a superior ability to pump nutrients from large volumes of soil compared to other commonly used fallow species. Sharrock, Sinclair, Gliddon, Rao, Barios, Mustonen, Smithson, Jones, and Goldbold (2004) found that T. diversifolia roots are associated with mycorrhizal fungi of the Glomaceae family, which are capable of high nutrient uptake even in nutrient depleted soils.

In agroecsystems where the major source of soil nutrients is derived from the input of plant biomass, the pruned biomass should meet a minimum concentration level for $\mathrm{N}$ and $\mathrm{P}$ to ensure mineralization and availability for plant uptake (Palm et al., 1997). These minimum concentrations range from 18 to $22 \mathrm{mg} \mathrm{N} \mathrm{g}^{-1}$ for N (Palm et al., 1997) and 3 to $5 \mathrm{mg} \mathrm{P} \mathrm{g}^{-1}$ for $\mathrm{P}$ (Marschner, 1995). Results from the present study showed that macronutrient concentrations in the aboveground biomass in each treatment were similar to those of other studies (Gachengo et al., 1999; Jama et al., 2000; Phiri et al., 2001; Salako and Tian, 2001; Opala et al., 2010; Sao et al., 2010) and were sufficient for $\mathrm{N}$, but not for $\mathrm{P}$. Although $\mathrm{P}$ concentrations in aboveground biomass were below the minimum level for mineralization, the high biomass production of $T$. diversifolia resulted in an input of $1.8 \mathrm{~g} \mathrm{P} \mathrm{m}^{-2}$ to the 
soil, which was $67 \%$ and $44 \%$ greater than that of the NF and CF treatments respectively. Young (2002) found that up to $1.5 \mathrm{~g} \mathrm{P} \mathrm{m}^{-2}$ can be returned to the soil from the input of pruning biomass from planted fallows; which will positively influence maize and bean yields (Araujo and Okaleye, 1997). For example, Kwabiah et al. (2003) found that the addition of $500 \mathrm{~g} \mathrm{~m}^{-2}$ (dry weight) T. diversifolia biomass led to an input of $1.5 \mathrm{~g} \mathrm{P} \mathrm{m}^{-2}$ to the soil. Slaats, van Heiden, Stockmann, and Wessel (1996) and Herrera (1997) also suggested that $T$. diversifolia, similar to other plants of the Asteraceae family, have the ability to attain a maximum biomass and nutrient accumulation during the first three to five years of growth.

A $\mathrm{C} / \mathrm{N}$ ratio below 20 in the $\mathrm{CF}$ treatment suggested that the equilibrium between mineralization and immobilization during decomposition may shift in favour of net mineralization (Constantinides and Fownes, 1994). A C/N ratio greater than 20, suggested that immobilization may be induced temporarily as a result of applying prunings in the NF and TF treatments. Biomass produced from fast-growing, $\mathrm{N}_{2}$-fixing species such as C. cajun, typically have a lower $\mathrm{C} / \mathrm{N}$ ratio compared to non- $\mathrm{N}_{2}$-fixing species such as $T$. diversifolia, but all fallow treatments fell outside the threshold value of 200:1 for initial net P mineralization (Kwabia et al., 2003). Young (2002) suggested that in fallow systems, mineralization-immobilization is time-dependent, implying that the synchronization between pruning biomass application and crop seeding is critical in order to maximize crop productivity. Cobo et al. (2002) found that the immobilization of $\mathrm{P}$ of decomposing organic matter below the critical value occurred only during the first two weeks of decay. Gachengo et al. (1999) observed that after three weeks of decomposition approximately $80 \%$ of the $\mathrm{N}$ and $\mathrm{P}$ had been released from $T$. diversofolia leaves, and $40 \%$ from Senna spectabilis (DC.) H. Irwin \& Barneby leaves. In Ghana, Partey et al. (2011) found that $T$. diversifolia had the highest percentage of decomposition and nutrient release rates compared to leguminous species. A potentially higher release of nutrients from pruning biomass in addition to the greater quantity of pruning biomass and nutrient input in the present study likely contributed to the elevated bean yield in the TF treatment where $T$. diversofilia prunings were not removed.

\subsection{Soil Phosphorus Fractions}

As expected, the concentrations of the different $\mathrm{P}$ fractions decreased with soil depth and were greatest in the top $12 \mathrm{~cm}$. Soil $\mathrm{P}$ was not influenced by either natural or improved fallow treatments over the 23 -week fallow phase. None of the fallow treatments were able to optimize P cycling by re-allocation of this nutrient from potentially labile and occluded fractions to $\mathrm{P}$ in the labile fraction and in the soil solution. Our results suggested that the influence of the different fallow treatments resulted in the inter-conversion of $\mathrm{P}$ between non-labile and labile fractions. On a Colombian Andosol, Basamba et al. (2008) also found no significant increase in soil N and P fractions as a result of the addition of $T$. diversifolia prunings. They suggested that both of these nutrients were likely immobilized. Satterlee, Yemefack, and Orr (2009) evaluated the effect of adding Entada abyssinica (Steud. Ex A. Rich.) cuttings on soil properties in Cameroon, and found no significant increase in total N, available $\mathrm{P}, \mathrm{Ca}$ or $\mathrm{Na}$ at a soil depth of 0-20 cm. Deery, Voroney, and Briceño (2005) also observed that the different soil P fractions were not redistributed in a frijol tapado system in Costa Rica after nine months of fallow. However, when fallow periods extended over the long-term ( $>1$ year), some effects on soil P fractions were observed, suggesting that longer fallow periods may provide sufficient time for the inter-conversion of the different soil $\mathrm{P}$ fractions. For example, on a Colombian volcanic-ash soil, Phiri et al. (2001) found that after more than one year of fallow with $T$. diversifolia, soil P fractions significantly increased as a result of changes in available P. In the southern USA, Matta-Machado and Jordan (1995) found that after three years of alley cropping, Albizia julibrissin Durazz was more efficient in tapping unavailable forms of soil $\mathrm{P}$ and achieved a higher $\mathrm{P}$ stock compared to an annual legume-based sole cropping system. In Nigeria, Adediran, Akande, Banjoko, Oluwatossin and Taiwo (2001) observed that after three years of fallow with C. cajun, levels of soil organic matter and fertility increased three fold.

Changes in the labile $\mathrm{P}$ fractions were more readily observed over the 23 -week fallow period in all three treatments compared to that of the potentially labile P (Fig. 2). This may be due to the depletion of P in the soil solution by roots of the growing vegetation, which is replenished in the solid phase via desorption (Jungk, Seeling, and Gerke, 1993). Additionally, there may be a rapid movement of P from the labile fraction to the soil solution (Jungk et al., 1993). In Andosols, phosphates that are released to the soil solution during organic matter mineralization tend to quickly convert $\mathrm{P}$ into more stable, but less labile, soil $\mathrm{P}$ fractions by $\mathrm{Fe}$ and $\mathrm{Al}$ oxides, allophane and recalcitrant organic matter (Zhongqi et al., 2004). Opala et al. (2010) also suggested that complexation and competition for sorption sites by the products of decomposing organic matter may occur. This results in a tight and conservative system in which P is cycled slowly and in small quantities (Smith, 2002).

In our study, the potentially labile and occluded fractions, including the residual P fraction, may have fluctuated due to the inherent variability of soil properties rather than as a response to fallow treatments. Kass, Somarriba, and Vasconcelos (1999) found a weak correlation between soil P fractions and plant response, and suggested that other factors such as soil type, texture, and nutrient status may affect the quantity of the different soil P fractions 
as much as agroecosystem management practices. Zhongqi et al. (2004) also suggested that soil chemical properties play a major role in controlling $\mathrm{P}$ dynamics and the mechanisms of inter-conversion between the different fractions. For example, the $\mathrm{NaOH}-\mathrm{P}_{0}$ constituted the largest fraction of potentially labile $\mathrm{P}$ in the soil in our study and that of other studies (Opala et al., 2010). This P fraction was shown to be an important source of P in low input biomass transfer systems (Beck and Sanchez, 1994), and the mineralization of this pool was likely responsible for providing $\mathrm{P}$ to the growing crop in the present study (Opala et al., 2010). However, significant increases in this fraction were only observed after 8-years of bush fallow (Tiessen, Alebo, and Sampaio, 1992). This suggested that in order to provide a significant source of $\mathrm{P}$ for crops, the continual and long-term input of large quantities of organic materials from the prunings of fallow species, including $T$. diversifolia are necessary. Basamba et al. (2008), and Mweta, Akinnifesi, Saka, Makumba, and Chokocho (2007) suggested that the addition of prunings from legumes in combination with inorganic $P$ fertilizers, especially in short-term and low input systems, may result in a reduced $\mathrm{P}$ sorption capacity of the soil and foster increased $\mathrm{P}$ uptake by the growing crop.

\section{Conclusions}

Results from the present study showed that high density plantings of leguminous and non-leguminous species in improved fallow systems contributed to a greater biomass production and greater input of nutrients to the soil than a natural fallow. Tithonia diversifolia had the greatest biomass production, which was likely due to its superior ability to exploit soil nutrients. The greater input of pruning biomass in the improved fallow with $T$. diversifolia compared to that of the natural fallow or the improved fallow with $C$. cajun also influenced bean grain yield positively. However, results from our study did not show a significant inter-conversion of soil $\mathrm{P}$ between the non-labile and labile fractions over the short term $(<1$ year), as a result of the low $\mathrm{P}$ concentrations in the slashed biomass and the high soil P-sorption capacity. Future studies should focus on increasing P availability in these soil types through a longer fallow period and/or the addition of soil amendments such as manure and/or calcium carbonate. Soil amendments such as poultry manure and calcium carbonate may play a critical role in removing the most limiting soil chemical factors in weathered Andosols.

\section{Acknowledgements}

We thank the University of Wales and the Danish Institute of Agricultural Sciences for providing financial assistance for our research. We also thank Dr. Gilberto Páez for statistical support and the anonymous reviewers that helped improve this manuscript.

\section{References}

Adediran, J.A., Akande, M.O., Banjoko, V.A. Oluwatossin, G.A., \& Taiwo, L.B. (2001). Influence of fallow on soil properties and yield of maize in south-western Nigeria. Journal of Agriculture in the Tropics and Subtropics, 102, 109-117.

Adetunji, M.T., \& Okaleye, K.A. (2001). Effect of incorporating legume hedgerow prunings on properties of an oxic Paleudolt in south-western Nigeria. Communications in Soil Science and Plant Analysis, 32, 331-451. http://dx.doi.org/10.1081/CSS-100103020

Aguiar, A.C.F. (2001). Efecto de especies usadas como abono verde en el enriquecimiento de la fertilidad del suelo y en el manejo de plagas. M.Sc. Thesis, CATIE, Costa Rica: Turrialba.

Araujo, A.P., Teixeira, M.G., \& de Almeida, D.L. (1997). Phosphorus efficiency of wild and cultivated genotypes of common bean (Phaseolus vulgaris L.) under biological nitrogen fixation. Soil Biology and Biochemistry, 29, 951-957. http://dx.doi.org/0038-071719571 7.

Barrios, E., Cobo, J.G., Rao, I.M., Thomas, R.J., Amezquita, E., Jimenez, J.J., \& Rondon, M.A. (2005). Fallow management for soil fertility recovery in tropical Andean agroeocsystems in Colombia. Agriculture, Ecosystems and Environment, 110, 29-42.

Basmaba, T.A., Barrios, E., Singh, B.R., \& Rao, I.M. (2008). Influence of planted fallow and manure application on soil quality and maize yields on a Colombian volcanic ash soil. Journal of Sustainable Agriculture, 32, 1-35. http://dx.doi.org/10.1080/10440040802121320

Beck, M.A., \& Sanchez, P.A. (1994). Soil phosphorus fraction dynamics during 18 years of cultivation on a typic Paleudult. Soil Science, 34, 1424-1431.

Cobo, J.G., Barrios, E., Kass, D.C.L., \& Thomas, R.L. (2002). Decomposition and nutrient release by green manures in a tropical hillside agroecosystem. Plant and Soil, 240, 331-342. http://dx.doi.org/10.1023/A:1015720324392

Cong, P.T., \& Merckx, R. (2005). Improving phosphorus availability in two upland soils of Vietnam using Tithonia diversifolia H. Plant and Soil, 269, 11-23. http://dx.doi.org/10.1007/s11104-004-1791-1 
Constantinides, M., \& Fownes, J.H. (1994). Tissue-to-solvent ratio and other factors affecting determination of soluble polyphenols in tropical leaves. Communications in Soil Science and Plant Analysis, 25, 3221-3227. http://dx.doi.org/10.1080/00103629409369260

Deery, D.D., Voroney, R.P., \& Briceño, J.A. (2005). Long-term effects of short-fallow fríjol tapado on soil phosphorus pools in Costa Rica. Agriculture, Ecosystems and Environment, 110, 91-103. http://dx.doi.org/10.1016/j.agee.2005.05.006

Gachengo, C.N., Palm, C.A., Jama, B., \& Othieno, C. (1999). Tithonia and senna green manures and inorganic fertilizers as phosphorus sources for maize in Western Kenya. Agroforestry Systems, 44, 21-36. http://dx.doi.org/10.1023/A:1006123404071

Garrity, D.P., \& Mercado, A.R. (1994). Nitrogen fixation capacity in the component species of contour hedgerows: how important? Agroforestry Systems, 27, 241-258. http://dx.doi.org/10.1007/BF00705059

Hedley, M.J., Stewart, J.W.B., \& Chauhan, B.S. (1982). Changes in inorganic and organic soil phosphorus fractions by cultivation practices and by laboratory incubations. Soil Science Society of America Journal, 46, 970-976.

Henry, A., Chaves, N.F., Kleinman, P.J.A., \& Lynch, J.P. (2010). Will nutrient-efficient genotypes mine the soil? Effects of genetic differences in root architecture in common bean (Phaseolus vulgaris L.) on soil phosphorus in a low-input agroecosystem in Central America. Field Crops Research, 115, 67-78. http://dx.doi.org/10.1016/j.fcr.2009.10.004

Herrera, F. (1997). Vegetation study in slash/mulch bean (frijol tapado). Agronomy in Mesoamerica, 8, 1-11.

Holdridge, L.R. (1987). Ecología Basada en Zonas de Vida. IICA, Costa Rica: San Jose.

International Soil Reference and Information Center. (1994). Soil reference profiles of Costa Rica. International Soil Reference and Information Centre (ISRC), The Netherlands: Wageningen.

Jama, B., Palm, C.A., Buresh, R.J., Niang, A., Gachengo, C., Nziguheba, G., \& Amadalo, B. (2000). Tithonia diversifolia as a green manure for soil fertility improvement in western Kenya: A review. Agroforestry Systems, 49, 201-221. http://dx.doi.org/10.1023/A:1006339025728

Jungk, A.O., Seeling B., \& Gerke, J. (1993). Mobilization of different phosphate fractions in the rhizosphere. In Barrow, N.J. (Ed.), Plant Nutrients: From Genetic Engineering to Field Practice (pp. 95-98). Kluwer Academic Publishers, The Netherlands: Dordrecht.

Kass, D.C.L, Somarriba, E., \& Vasconcelos, J.L.M. (1999). Soil phosphorus fractions in agroforestry systems: Effects of soil depth and sampling time. Agroforestry Forum, 9, 42-48.

Kass, D.C.L., \& Somarriba, E. (1999). Traditional fallows in Latin America. Agroforestry Systems, 47, 13-36.

Kwabiah, A.B., Stoskopf, N.C., Palm, C.A., \& Voroney, R.P. (2003). Soil P availability as affected by the chemical composition of plant materials: Implications for P-limiting agriculture in tropical Africa. Agriculture, Ecosysems and Environment, 100, 53-61. http://dx.doi.org/10.1016/S0167-8809(03)00171-3

Muchane, M., Jama, B., Otheino, C., Okalebo, R, Odee, D., Machua, J., \& Jansa, J. (2010). Influence of improved fallow systems and phosphorus application on arbuscular mycorrhizal fungi symbiosis in maize grown in Western Kenya. Agroforestry Systems, 78, 139-150. http://dx.doi.org/10.1007/s10457-009-9249-3

Mustonen, P.S. (2005). Biomass production, nutrients and root characteristics of fallow species and the utilization of its biomass as a phosphorus source for the common bean (Phaseolus vulgaris L.). Ph.D. Thesis, CATIE, Costa Rica: Turrialba.

Mweta, D.E., Akinnifesi, F.K., Saka, I.D.K., Makumba, W., \& Chokocho, N. (2007). Green manure from prunings and mineral fertilizer affect phosphorus adsorption and uptake by maize crop in a Gliricidia-maize intercrop. Science Research Essays, 2, 446-453.

Nwoke, O.C., Vanlauwe, B., Diels, J., Sanginga, N., Osonubi, O., \& Merckx, R. (2003). Assessment of labile phosphorus fractions and adsorption characteristics in relation to soil properties of West African savanna soils. Agriculture, Ecosystems and Environment, 100, 285-294. http://dx.doi.org/10.1016/S0167-8809(03)00186-5

Nziguheba, G., Merckx, R., Palm, C.A., \& Mutuo, P. (2002). Combining Tithonia diversifolia and fertilizers for maize production in a phosphorus deficient soil in Kenya. Agroforestry Systems, 55, 165-174. http://dx.doi.org/10.1023/A:1020540411245

Nziguheba, G., Palm, C.A., Buresch, R.J., \& Smithson, P.C. (1998). Soil phosphorus fractions and adsorption as affected by organic and inorganic sources. Plant and Soil, 198, 159-168. http://dx.doi.org/10.1023/A:1004389704235 
Oberson, A., Pypers, P., Bünemann, E.K., Frossard, E. (2011). Management impacts on biological phosphuris cycling in cropped soils. In Bünemann, E.K. (Ed.), Phosphorus in Action (pp. 431-457). Springer-Verlag, Germany: Berlin.

Oke, D.O. (2005). Changes in the nutrient status of a tropical Alfisol following application of leaf biomass of some agroforestry species. Journal of Agronomy, 4, 203-206

Opala, P.A., Okalebo, J.R., Othieno, C.O., \& Kisinyo, P. (2010). Effect of organic and inorganic phosphorus sources on maize yields in an acid soil in western Kenya. Nutrient Cycling in Agroecosystems, 86, $317-329$. http://dx.doi.org/10.1023/A:35400060421352.0003

Palm, C.A., Myers, R.K.J., \& Nandwa, S.W. (1997). Combined use of organic and inorganic nutrient sources for soil fertility maintenance and replenishment. In Buresh, R.J., Sánchez, P.A., Calhoum, F. (Eds.), Replenishing Soil Fertility in Africa (pp. 193-217). Soil Science Society of America, USA: Wisconsin.

Partey, S.T., Quashie-Sam, S.J., Thevathasan, N.V., \& Gordon, A.M. (2011). Decomposition and nutrient release patterns of the leaf biomass of the wild sunflower (Tithonia diversifolia): a comparative studies with four $\begin{array}{lllll}\text { leguminous agroforestry } \quad \text { species. } & \text { Agroforestry } & \text { Systems, } & 81, & 123-134 .\end{array}$ http://dx.doi.org/10.1023/A:35400019191254.0030

Phiri, S., Barrios, E., Rao, I.M., \& Singh, B.R. (2001). Changes in soil organic matter and phosphorus fractions under planted fallow and a crop rotation system on a Colombian volcanic-ash soil. Plant and Soil, 231, $211-223$. http://dx.doi.org/10.1023/A:1010310300067

Rao, D.L.N., \& Gill, H.S. (1995). Biomass production and nutrient recycling through litter from pigeonpea (Cajanus cajan L. Millsp.). Bioresource Technology, 54, 123-128. http://dx.doi.org/0960-8524/96/\$15.00

Rao, S.C., \& Northrup, B.K. (2009). Capabilities of four novel warm-season legumes in the Southern Great Plains: Biomass and forage quality. Crop Science, 49, 1096-1102. http://dx.doi.org/10.2135/cropsci2008.08.0499

Salako, F.K., \& Tian, G. (2001). Litter and biomass production from planted and natural fallows on a degraded soil in south-western Nigeria. Agroforestry Systems, 51, 239-251. http://dx.doi.org/10.1023/A:1010768419173

Sao, N.V., Mui, N.T. \& Binh D.V. (2010). Biomass production of Tithonia diversifolia (Wild Sunflower), soil improvement on sloping land and use as high protein foliage for feeding goats. Livestock Research and Rural Development, 22, 15-157.

SAS. (1999). The SAS Systems for Windows. Statistical Analysis System (SAS), v. 8. SAS Institute Inc., NC, USA: Cary

Satterlee, B.M., Yemefack, M., \& Orr, B.D. (2009). Maize yield and soil property responses to Entrada abyssinica (Steud. Ex A. Rich) cuttings in the Adamawa Lowlands, Cameroon. Journal of Food, Agriculture and Environment, 7, 192-196.

Sharrock, R.P., Sinclair, F.L., Gliddon, C., Rao, I.M. Barrios, E., Mustonen, P.J., Smithson, P., Jones, D.L., \& Godbold, D.L. (2004). A global assessment using PCR techniques of mycorrhizal fungal populations colonizing Tithonia diversifolia. Mycorrhiza, 14, 103-109. http://dx.doi.org/10.1007/s00572-003-0243-8

Slaats, J., Van Heiden, W., Stockmann, C., \& Wessel, M. (1996). Growth of the Chromolaena odorata fallow vegetation in semi-permanent food crop production systems in south-west Cote d'Ivoire. Netherlands Journal of Agricultural Science, 44, 179-192.

Smith, F.W. (2002). The phosphate uptake mechanism. Plant and Soil, 245, 105-114.

Sparks, D. (1996). Methods of soil analysis part 3: Chemical analysis. 1996. American Society of Agronomy, Wisconsin, USA: Madison.

Steel, G.C., Torrie, J.H., Dikey, D.A. (1997). Principles and procedures of statistics: A biometrical approach. McGraw-Hill, NY, USA: New York.

Tiessen, H., Alebo, I.H., \& Sampaio, E.V.S.B. (1992). Nutrient and soil organic matter dynamics under shifting cultivation in semi-arid north eastern Brazil. Agriculture, Ecosystems and Environment, 38, $139-151$. http://dx.doi.org/10.1016/0167-8809(92)90139-3

Tiessen, H., Stewart, J.W.B., \& Cole, C.V. (1984) Pathway transformation in soils of different pedogenisis. Soil Science Society of America Journal, 48, 853-858.

Young, A. (2002). Agroforestry for soil management. CAB International, United Kingdom: Wallingford.

Zhongqi, H., Griffin, T.S., \& Honeycutt, C. W. (2004). Evaluation of soil phosphorus transformations by sequential fractionation and phosphatase hydrolysis. Soil Science, 169, 515-527. 
Table 1. Aboveground nutrient concentrations and stocks from aboveground biomass under natural fallow (NF), and improved practices with $C$. cajun $(\mathrm{CF})$ and $T$. diversifolia monocultures harvested 24 weeks after planting in San Juan Sur, Costa Rica. Standard errors are given in parentheses $(n=4)$

\begin{tabular}{|c|c|c|c|}
\hline & Natural Fallow (NF) & C. cajan (CF) & T. diversifolia $(\mathrm{TF})$ \\
\hline $\mathrm{N}\left(\mathrm{mg} \mathrm{g}^{-1}\right)$ & $18.3(1.2)^{A}$ & $27.4(6.9)^{\mathrm{A}}$ & $19.8(4.3)^{\mathrm{A}}$ \\
\hline $\mathrm{P}\left(\mathrm{mg} \mathrm{g}^{-1}\right)$ & $1.5(0.1)^{\mathrm{A}}$ & $1.8(0.4)^{\mathrm{A}}$ & $1.7(0.3)^{\mathrm{A}}$ \\
\hline $\mathrm{K}\left(\mathrm{mg} \mathrm{g}^{-1}\right)$ & $18.4(1.2)^{\mathrm{A}}$ & $15.5(0.5)^{\mathrm{A}}$ & $20.1(3.0)^{\mathrm{A}}$ \\
\hline $\mathrm{Mg}\left(\mathrm{mg} \mathrm{g}^{-1}\right)$ & $2.4(0.2)^{\mathrm{A}}$ & $1.9(0.3)^{\mathrm{A}}$ & $2.7(0.4)^{A}$ \\
\hline $\mathrm{Ca}\left(\mathrm{mg} \mathrm{g}^{-1}\right)$ & $5.2(1.2)^{\mathrm{A}}$ & $3.4(0.6)^{\mathrm{A}}$ & $5.0(1.2)^{\mathrm{A}}$ \\
\hline $\mathrm{C}\left(\mathrm{g} \mathrm{m}^{-2}\right)$ & $183.6(23)^{A}$ & $235.1(18)^{\mathrm{B}}$ & $483.6(56)^{\mathrm{C}}$ \\
\hline $\mathrm{N}\left(\mathrm{g} \mathrm{m}^{-2}\right)$ & $7.5(0.5)^{\mathrm{A}}$ & $14.4(1.1)^{\mathrm{B}}$ & $21.4(2.2)^{\mathrm{C}}$ \\
\hline $\mathrm{P}\left(\mathrm{g} \mathrm{m}^{-2}\right)$ & $0.6(0.1)^{\mathrm{A}}$ & $1.0(0.1)^{\mathrm{B}}$ & $1.8(0.3)^{\mathrm{C}}$ \\
\hline $\mathrm{K}\left(\mathrm{g} \mathrm{m}^{-2}\right)$ & $7.5(0.2)^{\mathrm{A}}$ & $8.1(0.2)^{B}$ & $21.7(1.1)^{\mathrm{C}}$ \\
\hline $\operatorname{Mg}\left(g^{-2}\right)$ & $1.0(0.1)^{\mathrm{A}}$ & $1.0(0.1)^{\mathrm{A}}$ & $2.92(0.3)^{\mathrm{B}}$ \\
\hline $\mathrm{Ca}\left(\mathrm{g} \mathrm{m}^{-2}\right)$ & $2.1(0.2)^{\mathrm{A}}$ & $1.8(0.3)^{\mathrm{A}}$ & $5.4(1.2)^{\mathrm{B}}$ \\
\hline $\mathrm{C} / \mathrm{N}$ & $24.5(2.3)^{\mathrm{A}}$ & $16.4(1.1)^{\mathrm{B}}$ & $22.6(2.2)^{\mathrm{A}}$ \\
\hline $\mathrm{C} / \mathrm{P}$ & $298.5(10.2)^{\mathrm{A}}$ & $248.7(8.9)^{\mathrm{B}}$ & $263.4(9.5)^{\mathrm{C}}$ \\
\hline $\mathrm{N} / \mathrm{P}$ & $12.2(2.1)^{\mathrm{A}}$ & $15.2(1.5)^{\mathrm{A}}$ & $11.6(1.8)^{\mathrm{A}}$ \\
\hline
\end{tabular}

Values followed by the same uppercase letter, comparing nutrient concentrations, stocks and ratios between treatments are not significantly different at $\mathrm{p}<0.05$.

Table 2. Grain yield $\left(\mathrm{g} \mathrm{m}^{-2}\right)$ of two bean cultivars (Chirripo Rojo and Negro Huasteco) at harvest under natural fallow (NF) or in improved monoculture fallow with $C$. cajun (CF) and $T$. diversifolia (TF) monoculture with and without pruning biomass removed on an Andosol in San Juan Sur, Costa Rica. Standard errors are given in parentheses $(n=4)$

\begin{tabular}{|l|r|r|r|r|}
\hline & \multicolumn{2}{|c|}{ With Pruning Biomass Removed } & \multicolumn{2}{c|}{ Without Pruning Biomass Removed } \\
\hline & Chirripo Rojo & Negro Huasteco & Chirripo Rojo & Negro Huasteco \\
\hline Natural Fallow & $81(14)$ & $85(12)$ & $85(17)$ & $95(15)$ \\
\hline C. Cajun (CF) & $89(10)$ & $81(12)$ & $70(08)$ & $87(8)$ \\
\hline T. diversifolia (TF) & $71(16)$ & $66(12)$ & $101(16)$ & $98(19)$ \\
\hline
\end{tabular}

Table 3. Composition of soil phosphorus inorganic (Pi) and soil phosphorus organic (Po) fractions ( $\left.\mathrm{mg} \mathrm{kg}^{-1}\right) \mathrm{at}^{\mathrm{P}}$ 0-12 and 12-24 cm depths after 1, 20, and 23 weeks of natural fallow natural fallow (NF) or in improved monoculture fallow with $C$. cajun $(\mathrm{CF})$ and $T$. diversifolia (TF) monoculture in San Juan Sur, Costa Rica. Standard errors are given in parentheses $(n=4)$

\begin{tabular}{|c|c|c|c|c|c|c|c|c|c|}
\hline \multirow{2}{*}{$\begin{array}{l}\text { Soil Depth } \\
\text { (cm) }\end{array}$} & \multirow[t]{2}{*}{ Week } & \multirow[t]{2}{*}{ Treatment } & \multirow[t]{2}{*}{ Soil Solution Pi } & \multicolumn{2}{|c|}{ Labile P } & \multicolumn{2}{|c|}{ Potentially Labile P } & \multicolumn{2}{|c|}{ Occluded P } \\
\hline & & & & $\mathrm{NaHCO}_{3}-\mathrm{Po}$ & $\mathrm{NaHCO}_{3}-\mathrm{Pi}$ & $\mathrm{NaOH}-\mathrm{Po}$ & $\mathrm{NaOH}-\mathrm{Pi}$ & $\mathrm{HCl}-\mathrm{Pi}$ & Residual-P \\
\hline \multirow{9}{*}{$0-12$} & \multirow{3}{*}{1} & $\mathrm{NF}$ & $0.75(0.07)^{\mathrm{A}, \mathrm{a}}$ & $65(1)^{\mathrm{A}, \mathrm{a}}$ & $10.3(0.5)^{\mathrm{A}, \mathrm{a}}$ & $399(9)^{\mathrm{A}, \mathrm{a}}$ & $157(4)^{\mathrm{A}, \mathrm{a}}$ & $1.52(0.03)^{\mathrm{A}, \mathrm{a}}$ & $482(5)^{\mathrm{A}, \mathrm{a}}$ \\
\hline & & $\mathrm{CF}$ & $0.52(0.06)^{\mathrm{A}, \mathrm{a}}$ & $59(2)^{\mathrm{A}, \mathrm{b}}$ & $12.1(0.5)^{\mathrm{A}, \mathrm{b}}$ & $394(5)^{\mathrm{A}, \mathrm{a}}$ & $166(4)^{\mathrm{A}, \mathrm{b}}$ & $1.44(0.06)^{\mathrm{A}, \mathrm{b}}$ & $442(5)^{\mathrm{A}, \mathrm{b}}$ \\
\hline & & $\mathrm{TF}$ & $0.94(0.12)^{\mathrm{A}, \mathrm{b}}$ & $62(2)^{\mathrm{A}, \mathrm{c}}$ & $9.1(0.4)^{\mathrm{A}, \mathrm{c}}$ & $362(11)^{\mathrm{A}, \mathrm{b}}$ & $167(4)^{A, b}$ & $1.64(0.11)^{\mathrm{A}, \mathrm{c}}$ & $443(10)^{\mathrm{A}, \mathrm{b}}$ \\
\hline & \multirow{3}{*}{18} & $\mathrm{NF}$ & $0.82(0.10)^{\mathrm{B}, \mathrm{a}}$ & $62(1)^{\mathrm{B}, \mathrm{a}}$ & $11.4(0.4)^{\mathrm{B}, \mathrm{a}}$ & $365(11)^{\mathrm{B}, \mathrm{a}}$ & $176(3)^{\mathrm{B}, \mathrm{a}}$ & $1.70(0.05)^{\mathrm{B}, \mathrm{a}}$ & $432(4)^{\mathrm{B}, \mathrm{a}}$ \\
\hline & & $\mathrm{CF}$ & $0.83(0.16)^{\mathrm{B}, \mathrm{a}}$ & $59(2)^{\mathrm{B}, \mathrm{b}}$ & $12.1(0.5)^{\mathrm{B,a}}$ & $403(5)^{\mathrm{B}, \mathrm{b}}$ & $194(7)^{\mathrm{B}, \mathrm{b}}$ & $2.63(0.36)^{\mathrm{B}, \mathrm{b}}$ & $421(5)^{\mathrm{B}, \mathrm{b}}$ \\
\hline & & $\mathrm{TF}$ & $1.64(0.21)^{\mathrm{B}, \mathrm{b}}$ & $62(4)^{\mathrm{B}, \mathrm{b}}$ & $12.5(0.6)^{\mathrm{B}, \mathrm{a}}$ & $399(19)^{\mathrm{B}, \mathrm{b}}$ & $186(6)^{\mathrm{B}, \mathrm{c}}$ & $1.73(0.08)^{\mathrm{B}, \mathrm{a}}$ & $413(7)^{\mathrm{B}, \mathrm{c}}$ \\
\hline & \multirow{3}{*}{23} & NF & $0.60(0.06)^{\mathrm{C}, \mathrm{a}}$ & $58(2)^{\mathrm{C,a}}$ & $9.3(0.5)^{\mathrm{C}, \mathrm{a}}$ & $398(30)^{\mathrm{C}, \mathrm{a}}$ & $159(4)^{\mathrm{C,a}}$ & $1.60(0.04)^{\mathrm{C}, \mathrm{a}}$ & $459(3)^{\mathrm{C}, \mathrm{a}}$ \\
\hline & & $\mathrm{CF}$ & $0.46(0.07)^{\mathrm{C}, \mathrm{b}}$ & $52(2)^{\mathrm{C}, \mathrm{b}}$ & $8.9(0.8)^{\mathrm{C}, \mathrm{a}}$ & $338(6)^{\mathrm{cb}}$ & $168(6)^{\mathrm{C}, \mathrm{b}}$ & $1.56(0.07)^{\mathrm{C}, \mathrm{b}}$ & $430(6)^{\mathrm{C}, b}$ \\
\hline & & $\mathrm{TF}$ & $1.21(0.15)^{\mathrm{C,c}}$ & $56(2)^{\mathrm{Ca}}$ & $7.2(0.5)^{\mathrm{Ca}}$ & $359(24)^{\mathrm{C,b}}$ & $161(6)^{\mathrm{C}, \mathrm{a}}$ & $1.73(0.11)^{\mathrm{Caa}}$ & $436(10)^{\mathrm{C}, \mathrm{b}}$ \\
\hline \multirow{9}{*}{$12-24$} & \multirow{3}{*}{1} & $\mathrm{NF}$ & $0.16(0.04)^{\mathrm{A}, \mathrm{a}}$ & $47(3)^{\mathrm{A}, \mathrm{a}}$ & $6.7(1.3)^{\mathrm{A}, \mathrm{a}}$ & $328(18)^{\mathrm{A}, \mathrm{a}}$ & $119(5)^{\mathrm{A}, \mathrm{a}}$ & $2.09(0.07)^{\mathrm{A}, \mathrm{a}}$ & $442(6)^{\mathrm{A}, \mathrm{a}}$ \\
\hline & & $\mathrm{CF}$ & $0.25(0.01)^{\mathrm{A}, \mathrm{b}}$ & $45(1)^{\mathrm{A}, \mathrm{a}}$ & $7.7(0.4)^{\mathrm{A}, \mathrm{a}}$ & $324(7)^{\mathrm{A}, \mathrm{a}}$ & $126(1)^{\mathrm{A}, \mathrm{b}}$ & $1.80(0.11)^{\mathrm{A}, \mathrm{b}}$ & $401(6)^{\mathrm{A}, \mathrm{b}}$ \\
\hline & & $\mathrm{TF}$ & $0.22(0.02)^{\mathrm{A}, \mathrm{c}}$ & $46(1)^{\mathrm{A}, \mathrm{a}}$ & $6.4(0.4)^{\mathrm{A}, \mathrm{a}}$ & $279(7)^{\mathrm{A}, \mathrm{b}}$ & $121(4)^{\mathrm{A}, \mathrm{a}}$ & $1.71(0.02)^{\mathrm{A}, \mathrm{b}}$ & $410(11)^{\mathrm{A}, \mathrm{b}}$ \\
\hline & \multirow{3}{*}{18} & $\mathrm{NF}$ & $0.14(0.02)^{\mathrm{A}, \mathrm{a}}$ & $42(4)^{\mathrm{B}, \mathrm{a}}$ & $5.4(0.8)^{\mathrm{A}, \mathrm{a}}$ & $319(20)^{\mathrm{A}, \mathrm{a}}$ & $134(4)^{\mathrm{B}, \mathrm{a}}$ & $5.25(2.13)^{\mathrm{B}, \mathrm{a}}$ & $392(6)^{\mathrm{B}, \mathrm{a}}$ \\
\hline & & $\mathrm{CF}$ & $0.16(0.03)^{\mathrm{B}, \mathrm{a}}$ & $40(5)^{\mathrm{A}, \mathrm{a}}$ & $5.9(0.8)^{\mathrm{B}, \mathrm{a}}$ & $309(40)^{\mathrm{A}, \mathrm{a}}$ & $139(10)^{\mathrm{B}, \mathrm{a}}$ & $4.02(0.51)^{\mathrm{B}, \mathrm{a}}$ & $372(11)^{\mathrm{B}, \mathrm{b}}$ \\
\hline & & $\mathrm{TF}$ & $0.30(0.12)^{\mathrm{A}, \mathrm{a}}$ & $50(7)^{\mathrm{A}, \mathrm{a}}$ & $6.0(1.3)^{\mathrm{A}, \mathrm{a}}$ & $334(38)^{\mathrm{Ba}}$ & $140(17)^{\mathrm{B}, \mathrm{a}}$ & $3.96(0.35)^{\mathrm{B}, \mathrm{a}}$ & $380(16)^{\mathrm{B}, \mathrm{b}}$ \\
\hline & \multirow{3}{*}{23} & $\mathrm{NF}$ & $0.26(0.05)^{\mathrm{B}, \mathrm{a}}$ & $35(4)^{\mathrm{Caa}}$ & $5.7(1.1)^{\mathrm{A}, \mathrm{a}}$ & $309(40)^{\mathrm{A}, \mathrm{a}}$ & $109(7)^{\mathrm{C}, \mathrm{a}}$ & $1.34(0.03)^{\mathrm{C}, \mathrm{a}}$ & $394(10)^{\mathrm{B}, \mathrm{a}}$ \\
\hline & & $\mathrm{CF}$ & $0.26(0.05)^{\mathrm{A}, \mathrm{a}}$ & $30(3)^{\mathrm{Caa}}$ & $4.2(0.6)^{\mathrm{c}, \mathrm{b}}$ & $236(11)^{\mathrm{A}, \mathrm{b}}$ & $108(5)^{\mathrm{C}, \mathrm{a}}$ & $1.51(0.02)^{\mathrm{C}, \mathrm{a}}$ & $365(9)^{\mathrm{B}, \mathrm{b}}$ \\
\hline & & $\mathrm{TF}$ & $0.20(0.07)^{\mathrm{A}, \mathrm{a}}$ & $39(4)^{\mathrm{Ba}, \mathrm{a}}$ & $5.0(1.5)^{\mathrm{A}, \mathrm{a}}$ & $276(37)^{\mathrm{A}, \mathrm{a}}$ & $121(13)^{\mathrm{A}, \mathrm{a}}$ & $1.34(0.09)^{\mathrm{C}, \mathrm{a}}$ & $388(15)^{\mathrm{B}, \mathrm{a}}$ \\
\hline
\end{tabular}

Values followed by the same upper case letter, comparing differences in P between weeks and within treatments at a depth of $0-12 \mathrm{~cm}$ and $12-24 \mathrm{~cm}$ are not significantly different at $\mathrm{p}<0.05$. Values followed by the same lower case letter, comparing differences in P between treatments within the same sampling time at 0-12 $\mathrm{cm}$ and 12-24 $\mathrm{cm}$ depth, are not significantly different at $\mathrm{p}<0.05$ 


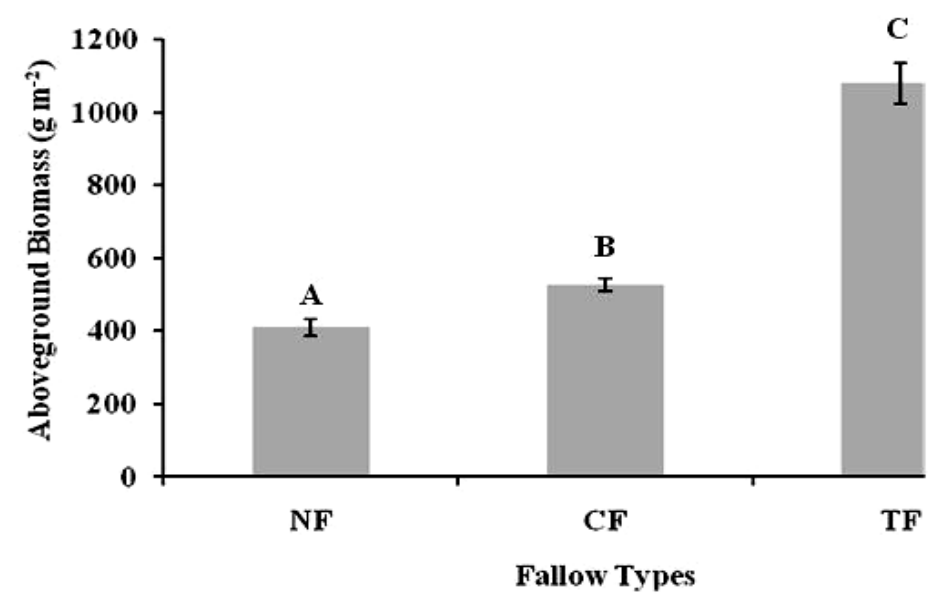

Figure 1. Aboveground biomass production $\left(\mathrm{g} \mathrm{m}^{-2}\right)$ of natural fallow (NF), and improved fallows with $C$ cajun . (CF) and T. Diversifolia (TF) in monoculture after 24 weeks of growth on an Andosol in San Juan Sur, Costa Rica. Values with the same upper case letters indicate no statistical difference at $\mathrm{p}<0.05(\mathrm{n}=4)$

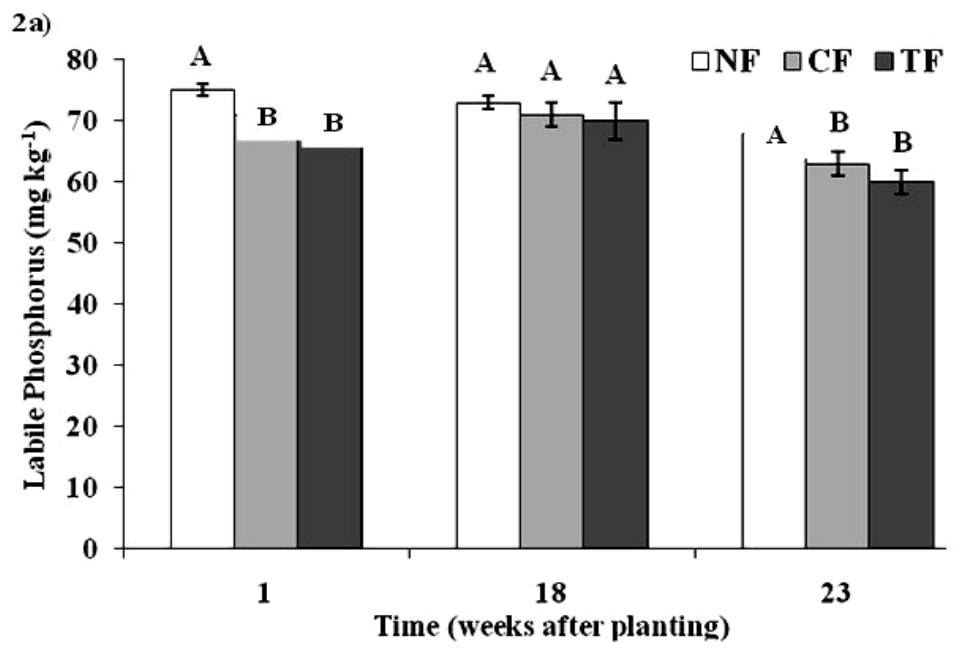

2b)

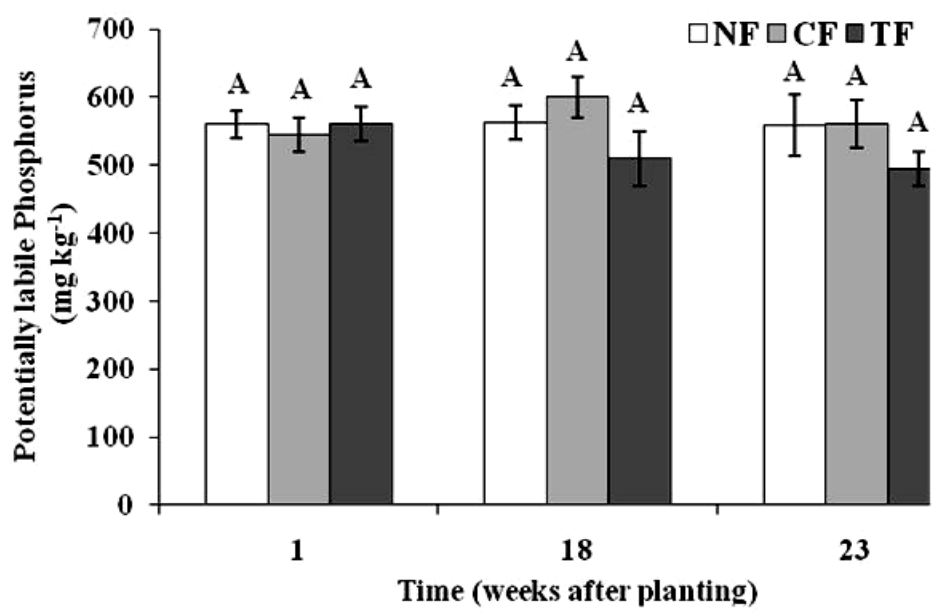

Figure 2. Labile phosphorus fractions at a depth of 0-12 cm (a), and potentially labile phosphorus fractions at a depth of 0-12 cm (b), after 1, 18 and 23 weeks after growth under natural fallow (NF) and improved fallows with C. Cajun (CF) and T. Diversifolia (TF) in monoculture on an Andosol in San Juan Sur, Costa Rica (n=4) 